\title{
From the Faculty of Theology of the Kraków Academy to the John Paul II Pontifical University in Kraków 1397-20091
}

\begin{abstract}
In 1397 Pope Boniface IX, at the request of King Władysław Jagiełło and his wife Saint Jadwiga (Hedvig), Queen of Poland, called into being a Faculty of Theology in Studium Generale in Kraków. Scientific talents and hard work together with universal support of the state and Church authorities set the young faculty on its feet immediately. The period of the first hundred years was a golden age in the development of the Faculty. It rapidly won fame not only in Poland but also in all Europe, mainly because of the speeches of its theologians at the Councils of Constance and Basle. The fame of Kraków theologians spread throughout Europe during the period of the Council of Basle. During the period of the Reformation, professors of the university, then called the Kraków Academy, were involved in defence of the Catholic Church. During the Council of Trent (1545-1563) in the university circles there appeared splendid works impugning the Protestant and neo-Arian views. The codification of dogmas at the Council of Trent facilitated the teaching methods and acceptance of Summa Theologica by St. Thomas Aquinas as the best interpretation of the Christian outlook.

In 1795, Poland was completely erased from the map of Europe, torn and divided between Prussia, Russia and Austria. Kraków came under the sway of the Austrians, beginning a difficult period for the Faculty of Theology and the whole University. The Austrian system concerning politics and the Church, called Josephinism, was damaging to the theological studies there. The re-organisation of the Faculty in 1880 was very crucial. It restored full academic rights, and the increasing number of chairs initiated a period of intense re-building of the University's role in Polish culture, which it had enjoyed in the $15^{\text {th }}-16^{\text {th }}$ centuries. In $1880-1939$, the Faculty experienced something similar to a second spring, comparable with its golden $15^{\text {th }}$ century. The successful development of the Faculty was dramatically interrupted by
\end{abstract}

1 The text is an updated version of my article Theology at Kraków Academy published in: Ztota Księga Papieskiej Akademii Teologicznej (Liber aureus Pontificiae Academiae Theologicae), ed. S. Piech, Kraków 2000, pp. 49-70. 
the outbreak of World War II in September 1939 and the following gehenna of the Nazi occupation.

After the war, the struggle with the Church, atheistic policy and laicisation planned by the communist government prevented a normal development of the Faculty outright. The faculty's existence was in jeopardy. The threat of liquidation appeared unavoidable and then it became fact. The Council of Ministers of the Polish People's Republic by its unilateral decision of 1954, without any agreement with the Church, connected the Faculty of Theology of the Jagiellonian University to the Faculty of Catholic Theology of Warsaw University to form the Academy of Catholic Theology in Warsaw, which had just been created by the government. The Faculty of Theology in Kraków survived as an independent faculty due to the uncompromising attitude of the Apostolic See and the Kraków bishops. In 1974 the Faculty, functioning within the Metropolitan Seminary, was bestowed the title 'pontifical.' A turning point in the history of the Faculty was its re-structuring as an academy with three faculties. In 1981, Pope John Paul II established the Pontifical Academy of Theology. In 2009, Pope Benedict XVI elevated it to the John Paul II Pontifical University.

\section{Keywords}

Faculty of Theology in Kraków, Kraków Academy, Jagiellonian University, Pontifical Academy of Theology in Kraków, John Paul II Pontifical University.

Pope Boniface IX in his bull Eximiae devotionis affectus of 11 January 1397, at the request of King Władysław Jagiełło and his wife Saint Jadwiga (Hedvig), Queen of Poland, called into being a Faculty of Theology in Studium Generale in Kraków, which had been founded in 1364 by King Kazimierz Wielki (Casimir the Great). The organisation of the Faculty's scientific aspect, following the Queen's order, had been prepared at least from 1396 by Jan Isner under the supervision of his master, Mateusz of Kraków, the outstanding theologian and later bishop of Worms. Professors from the University of Prague and Polish officials headed by Bishop Piotr Wysz of Kraków supported this work. Young Jadwiga, aged 25, after the death of her three-week-old daughter, Elżbieta Bonifacja, sensing her own death, donated all her jewellery for the purpose of re-founding the Kraków University, as if she gave the University her dowry and thus creating its financial basis. The dowry was not small at all. It was worth 3,000 ancient monetary units (grzywna). If in those days a building in the centre was worth about 600 units, then the money from selling Jadwiga's jewellery was enough to buy two or three buildings and use the rest to convert the buildings to the needs of the university. A year after the Queen's death, on 26 July 1400, her gift enabled King Władysław Jagiełło to issue an act re-founding the Kraków University. 
With this act a new academic yearofficially began. The Faculty of Theology ranked highest in the University's hierarchy and was to serve the work of evangelization of the vast Lithuanian-Russian lands.

\section{Golden age}

At first the Kraków Faculty of Theology remained under the influence of the Faculty of Theology of the University of Prague. However, the greatest authority for all theologians of that period was the Sorbonne in Paris, which was used as a model when the Kraków Faculty was created. The lecturers of the Bible and dogmatic theology followed the Paris example for a long time. Scientific talents and hard work together with the universal support of the state and Church authorities set the young faculty on its feet immediately. The period of the first hundred years was a golden age in the development of the Faculty. It won fame rapidly not only in Poland but also throughout Europe, mainly because of the speeches of its theologians at the Councils of Constance and Basle. The fame of Kraków theologians particularly spread accross Europe during the period of the Council of Basle. It was the time of a scandalous destruction of the unity of the Church called the Great Schism. Many leading Kraków theologians, with their urgent desires to restore the unity and bring about some religious revival, defended the teaching of the council's supremacy over the Pope (counciliarism). Although the teaching was later condemned by the Church as erroneous, the theological reflections of the Kraków theologians, characterised by a high scientific level and zeal in the cause of the Church reform, won common approval from European universities.

A famous theologian of that period was Jakub of Paradyż (1380-1464), the glory of the Kraków Studium Generale, one of the most outstanding European theologians at the close of the Middle Ages. Among the Kraków theologians, promoters of the council's supremacy, he held the most extreme opinion that only a universal council had the highest authority in the Church. He limited the Pope's authority only to matters of administration. Benedykt Hesse of Kraków (ca. 1389-1456) wrote an extremely long Commentum in Evangelium S. Mathaei ${ }^{2}$ in the spirit of Thomism. His commentaries on Quatuor libri

\footnotetext{
The Jagiellonian Library, Mss 1364, 1365, 1366, 1368.
} 
sententiarum $^{3}$ by Piotr Lombard were used at the Faculty of Theology not only in the $15^{\text {th }}$ century, but also in almost the whole $16^{\text {th }}$ century. Hesse was a fervent propagator of the council's supremacy. He also carried out polemics with the Hussites. Other distinguished professors of that period were Jan of Dąbrówka (1400-1472), whose commentary, printed in many copies, on Quatuor libri sententiarum by Piotr Lombard was used as a university manual for a long time; Franciszek of Brzeg (ca. 1370-1432), Maciej of Łabiszyn (ca. 1400-ca. 1452), Paweł of Pyskowice (ca. 1394-1470), Maciej of Sąspów (ca. 1408-1473) and Jan of Słupcza (1403-1488), authors of numerous philosophical and theological works. The Kraków University theologians of the golden age raised the Polish theology to the European level. They strongly defended the Catholic faith. They opposed effectively the theological errors of John Wycliffe and the religious innovations of John Huss.

In the atmosphere of piety and virtuous instruction in fidelity to the Catholic Church numerous professors and students reached the level of human perfection. The work of their lives and efforts was a specific climate of the royal city in the $15^{\text {th }}$ century called felix saeculum Cracoviae, which yielded many holy professors and students. The pride of Kraków University was St. John of Kęty (1390-1473), professor of theology, known for his piety, good heart for youth and mercy for the poor, whose cult began to spread immediately after his death. Professor Izajasz Boner, Servant of God, lived a life of holiness as well. He belonged to the Monks of St. Augustine, living in the monastery at the Church of St. Catherine. There were also holy students: St. Stanisław Kazimierczyk, a Lateran canon regular, St. Szymon of Lipnica, a Franciscan Bernardine, and Michał Giedroyć, Servant of God, called Blessed, from the monastery located at St. Mark's in Kraków.

At the beginning of the $16^{\text {th }}$ century Jan of Oświęcim, called Sacranus, was famous for his theological works (1443-1527). He was the author of a wellknown treatise Elucidarius errorum ritus Ruthenici (ca.1501), directed against the Orthodox Church. He was an opponent of the union between the Orthodox Church and the Roman Catholic Church, which was based on the principle of equality of rites. His demand of a second baptism from those Orthodox who wanted to join the Catholic Church led to working out a precise teaching of the Catholic Church on baptism received in the Orthodox Church. The problem

\footnotetext{
The Jagiellonian Library, Mss, 1518, 1519, 1531, 2091.
} 
was brought to the Holy See, which explained that there was no need of a new baptism for those having been baptised in the Orthodox Church.

\section{In the course of Catholic reform}

During the period of Reformation, professors of the university, then called the Kraków Academy, were involved in the course of defence of the Catholic Church. During the Council of Trent (1545-1563) in the university circles there appeared splendid works impugning Protestant and neo-Arian views. In their teachings and polemics, in the spirit of humanism, the Kraków professors more and more frequently began referring to the biblical texts in the original languages. In their polemics they used their vernacular, which had been hardly used by Catholic theologians. Mateusz of Kościan, called Costenus (d. in 1545), used the Hebrew text in his explanations of the Psalms and the prophesies of Isaiah, Jeremiah and Ezekiel ${ }^{4}$. His short work Examen spirituum et visionum cum parenesi ad agendam poenitentiam was devoted to the discernment of spirits, which was an important matter in the theology of spiritual life ${ }^{5}$. Costenus, influenced by humanism, frequently used the works of the Fathers of the Church, ancient Christian writers and the works of ancient Greek and Latin authors.

In 1553, Scopus biblicus Veteris et Novi Testamenti ${ }^{6}$ by Wojciech Nowopolczyk (ca. 1504-1559), known as Novicampianus, appeared in Kraków. This short work, written in popular Latin, which presented a clear explanation of basic dogmas and principles of Christian life, using a modern biblical method, was widely accepted, the evidence being six international editions? In 1559, another controversial work by Novicampianus was published, namely Apologia... pro catholica fide et doctrina de veritate Corporis Christi Jesu in Eucharistia de caeterisque sacramentis ${ }^{8}$, under the evident influence of the monumental work of Cardinal Stanisław Hozjusz, Confessio catholicae

4 The Jagiellonian Library, Mss 2310, 2046.

5 Cracoviae 1542 excussum in Officina Hieronimi Vietoris.

6 Cracoviae 1553, Lazarus Andreae.

7 Antwerpiae 1555, 1559, 1562, 1566, 1572 apud Joannem Bellerum; Lugduni 1572 apud Alexandrum de Marsiliis.

8 Cracoviae 1559 apud Lazarus Andreae. 
fidei christiana $a^{9}$, which was an example for almost all polemicists fighting with Protestantism and partly with neo-Arian movements in the $16^{\text {th }}$ century. In his Apology Novicampianus discussed almost all subjects of the polemic between Catholics and Protestants. His contemporaries considered him to be one of the most outstanding university professors. Because his works were published in several editions in Antwerp, Cologne and Lyons; he was also well known abroad.

Antoni of Napachań (de Appachanie, 1494-1561), professor of the Faculty of Theology, published Enchiridion, to iest książki ręczne o nauce chrześcijańskiej, czego się chrześcijański człowiek dzierżeć ma czasu różności wiary (Enchiridion, i.e. manuals on Christian teaching, what a Christian has to hold to in times of various faiths $)^{10}$. It was a humanistic exposition of the basic truths of faith attacked by Protestants. Jan Leopolita 'the younger,' a professor of the Holy Scriptures, (ca. 1523-1572), attained a lasting place in the history of Polish literature by editing and publishing the first complete Catholic translation of the Bible in Polish, known as Biblia Leopolity (Leopolita's Bible) ${ }^{11}$. Jakub Górski (1525-1585), although he was not a professor at the Faculty of Theology but a professor of law, justified his theological writings with a conviction that in time of fire all were called to save the edifice of the Church. In his work Praelectionum Plocensium, after he had presented the Catholic teaching in a positive way, he answered the objections of the heretics ${ }^{12}$. He included the decrees of the Council of Trent in the theses condemning the heretics.

The university circle produced Stanisław Sokołowski, called Socolovius, (1537-1593), an eminent theologian and preacher of Stefan Batory, King of Poland. He made himself known among Protestants and won European fame with his well-known Censura Orientalis Ecclesiae, in which he commented on the correspondence between Jeremiah II Tranos, Patriarch of Constantinople, and the University of Tübingen, the subject being the unity of the Greek Orthodox Church and the Lutheran Church, proposed by German Protestants, and the Patriarch's rejection of the Augsburg Confession

9 Moguntiae 1557 excudebat Franciscus Behem.

${ }^{10}$ Kraków 1558 at Dziedzice Marka Szarffenbergera.

${ }^{11}$ Kraków 1561 in Officina Szaeffenberg.

${ }_{12}$ Vol. 1-2, Coloniae 1572-1580 apud Maternum Cholinum, vol. 3, Cracoviae 1580 in Officina Lazari, vol. 4-5, Coloniae 1582-1583 apud Maternum Cholinum. 
as contrary to the traditional Christian teaching ${ }^{13}$. The work provoked evoked several years' polemic and made Sokołowski extremely famous in the highest Catholic circles, with Pope Gregory XIII at the head. This book had five editions in Ingolstadt, Dyling ${ }^{14}$, Cologne ${ }^{15}$ and Paris ${ }^{16}$ (twice in German ${ }^{17}$ ). Another work, which assured him a lasting place in theology, was De verae et falsae Ecclesiae discrimine... libri tres ${ }^{18}$ which was also directed against Protestantism. He adapted the four characteristics of the Church from the Nicene-Constantinople Creed (one, holy, universal and apostolic), and the scheme of his work followed the treatise of Hozjusz's school. He stressed the role of the Pope as the bishop of the universal Church. In his definition of papal infallibility he was close to the theses of the First Vatican Council. The book was printed three times in Germany ${ }^{19}$. In the $17^{\text {th }}$ century his Partitiones ecclesiasticae ${ }^{20}$ was used as a manual of preaching at the university.

Among the professors of the Kraków Academy in the $17^{\text {th }}$ century, the distinguished figure, according to European standards, was Adam of Opatów, (Opatovius 1574-1647), who enjoyed a high reputation of being an outstanding scholar among his contemporaries. In his two large works: Tractatus de sacramentis in genere et specie ${ }^{21}$, Tractatuum theologicorum ex Ip. Doctoris Angelici ... pars prima ${ }^{22}$, Tractatuum theologicorum ex 1. 1 et ex 2. 2, Summae D. Thomae ... pars secunda ${ }^{23}$ he embraced the entire contemporary theology unfolded ad mentem sancti Thomae. These works, especially the treatise on sacraments, were obligatory manuals at the Faculty of Theology of the Kraków Academy. Adam Opatowski, who died in odore sanctitatis, was also a theologian of spiritual life and a hagiographer.

${ }^{13}$ Cracoviae 1582 in Officina Lazari.

${ }^{14}$ Dylingae 1582 excudebat Joannes Mayer.

${ }^{15}$ Coloniae 1583 apud Maternum Cholinum.

${ }^{16}$ Parisiis 1584 apud Arnoldum Sittart.

${ }^{17}$ Cöln 1582 Maternus Cholinus, Ingolstadt 1583 bey David Sartorio.

${ }^{18}$ Cracoviae 1583 in Officina Lazari. Ederi.

${ }^{19}$ Coloniae 1584 apud Maternum Cholinum, Ingolstadii 1854, 1586 ex Officina Wolfgangi

${ }^{20}$ Cracoviae 1589 in Officina Lazari.

${ }^{21}$ Cracoviae 1642 in Officina Matthi. Andreoviensis.

${ }^{22}$ Cracoviae 1644 in Officina Typogr. Christophorii Schedelli.

${ }^{23}$ Cracoviae 1645 in Officina Christophori Schedelli. 
Szymon Stanisław Makowski (ca. 1612-1683), left several volumes on philosophy, dogmatics and moral theology and preaching. In his works, the Polish moral theology of the $17^{\text {th }}$ century reached its heights of faith. Szymon Makowski was able to work out his own, positive and deeply biblical image of Christian life and in an original way he linked it with a method of teaching elaborated by Spanish theologians. Among his theological and moral works, the most important was Explanatio decalogi ${ }^{24}$. His most distinguished dogmatic work was Theologia Christiana ${ }^{25}$. Both works were obligatory manuals for students.

\section{The organisation of studies}

The mediaeval structure of theological studies created in the golden age at the Kraków Academy remained till the reform of Hugo Kołłątaj in 1780. A candidate for theological studies had first to complete liberal arts with a master's degree. Statuta Theologicae Facultatis Studii Cracoviensis, elaborated in 1521 by Marcin Biem, also called Marcin of Olkusz, allowed philosophers without magisterium in artibus to begin theological studies. However, they were required to hold two public disputes absque dispensatione at the Faculty of Liberal Arts within the first two years of theological studies. A student of theology attended lectures on the Holy Scriptures during these first two years. After their completion, he was baccalarius-cursor. For the next two years he lectured on the Bible under the supervision of his professor and continued his theological studies. He read Quatuor libri sententiarum by Piotr Lombard. Then he took an exam in the form of dispute, after which he gained the degree of baccalarius-sententiarius, and he expounded the four books of Sentences. After the completion of lectures and an exam in the form of debate, a student of theology received licentiam docendi, i.e. permission to lecture theology on his own. The licentiate made him a member of the Faculty of Theology. The way pro loco inter Doctores Sacrae Theologiae was opened to him. The reform of Rector Mikołaj Dobrocieski in 1603/04 required three years of studies ante primam Lauream in Theologia and two ante Licenciaturam. The reform introduced Summa Theologica by Thomas

\footnotetext{
${ }^{24}$ Cracoviae 1682 apud Albertum Gorecki.

${ }^{25}$ Cracoviae 1682 in Officina Alberti Gorecki.
} 
Aquinas instead of Quatuor libri sententiarum by Piotr Lombard. Only doctors of theology could expound the Bible. The time of numerous debates was shortened.

Only a student with a master's degree in arts and a completed five-year course of theology could pursue a doctor's degree. The way to a doctor's degree in theology, which was the summit of an academic career, was long. A doctor's degree in theology was gained by a man of about 50 years old. Its completion was not easy at all. The Faculty of Theology at the Kraków Academy, similarly to the Faculty of Theology in Paris, had very demanding requirements. The long period of studies and the exceptionally rigorous demands placed on the candidates caused most professors of theology to complete their doctor's degrees abroad, particularly in Rome where they could achieve the degree more quickly and easily. The theological studies in Padua, Bologna and Rome, which the Kraków professors were familiar with, promoted two kinds of doctors. The first kind was the ones who attained ius collegii, i.e. became members of university staff. The second embraced the so-called extranei, who received the title without all rights to teach at a university. The Roman University Sapienza treated the extranei with some remission. They did not have to attend lectures. It was enough for them to pass obligatory exams and conduct a debate. A similar practice was common all over Europe. The Kraków Faculty of Theology showed a justifiable resistance to those easier conferrals of the doctor's degree. Doctores romani were permitted to conduct a debate and become members of the Faculty after a long period of waiting, sometimes lasting even 25 years. Only in 1690, following the example of Western universities, in particular the Italian ones, the rigid rules were waived, especially for candidates not pursuing a university career. Many members of the cathedral chapter and other ambitious clergy were conferred the doctor's degree in a shorter procedure, without the arduous attendance of the whole course. They did not become members of the university staff. These procedures were commonly applied only in the $17^{\text {th }}$ century when just a debate was required.

The Academy adhered to the teaching of St. Thomas Aquinas with a special predilection and followed it till the end of the $18^{\text {th }}$ century. Under the influence of the works of Melchior Cano, a famous Dominican theologian, and the Jesuit ratio studiorum, one could see the division into the scholastic and positive theology in the teachings of Kraków academic theologians already at the beginning of the $17^{\text {th }}$ century. In practice the exposition of scholastic theology, i.e. the explanation of Summa Theologica by St. Thomas 
Aquinas, embraced dogmatic and moral questions, sometimes interwoven with a polemic against heretics. The positive theology included the study of the Bible and the Tradition connected with disputes of contrary views.

The codification of dogmas at the Council of Trent facilitated the teaching methods and acceptance of Summa Theologica by St. Thomas Aquinas as the best interpretation of the Christian outlook. In the first half of the $17^{\text {th }}$ century the academic theologians yielded to Jesuits who were unrivalled leaders in controversial literature. However, the teaching levels were equal, the only difference being a divergent treatment of scholarly writing. The Jesuits were called to apostleship in word and pen whereas the Academy professors defined the basic duty as didactics. This attitude was evident in literary heritage. Generally speaking, apart from a few larger works they left brief treaties in the field of philosophy, theology, astronomy, mathematics and medicine, theses of licentiate and doctoral disputes, sermons, speeches prepared for special occasions and often used panegyrics and very popular calendars. These diversified works were an expression of the encyclopaedic education of university theologians, who, usually earlier, or sometimes at the same time, lectured at other university faculties.

During the reigns of the Saxon kings: August II the Strong (1697-1733) and August III (1733-1763) new trends appeared at the university after the Kraków diocese and the Academy had been taken over by Bishop Andrzej Stanisław Załuski (1695-1758), one of the most eminent and erudite patrons of science in the Saxon times. His programme of the university reform again introduced the neglected teaching of Hebrew from the first half of the $18^{\text {th }}$ century; the purpose being the deepening of biblical studies. In 1757, he founded the Academic Spiritual Seminary, where the professors of the Faculty of Theology gave lectures.

During the reign of the last Polish king Stanisław August Poniatowski (1764-1795), defined as a period of many-sided revival, state reforms, economic boom and development of national culture, the Faculty of Theology at the Kraków Academy was evidently restored. However, these were times when the independence of Poland was seriously threatened. In 1772, the three neighbouring monarchies: Prussia, Russia and Austria made the first partition of Poland. In 1773, the National Education Commission was called into being. It could be called the first European ministry of education. In the same year the first Chair of the History of the Church was created at the Kraków Academy. Its first professor was Fr. Józef Alojzy Putanowicz. 
As a delegate of the National Education Commission Hugo Kołłątaj carried out a thorough reform of the Kraków Academy, which he changed into the General Royal School (Szkoła Główna Koronna). The Theological and Canonical College, established at the School, embraced only four theological chairs: Biblical Studies, Dogmatics, Moral Theology and Church History, and two chairs of Canon Law. In 1783, the College was incorporated into the Moral College within which a School of Theology was created. In a way the reform of Hugo Kołłątaj lessened the status of the Faculty of Theology from a leading position in the university structure.

In 1795, Poland was completely erased from the map of Europe, torn and divided between Prussia, Russia and Austria. Kraków came under the sway of the Austrians, beginning a difficult period for the Faculty of Theology and the whole University. Frequent political changes on the map of Europe left painful traces. The Austrian system concerning politics and the Church, called Josephinism, had a damaging effect on the theological studies. In 1802, the Chair of Pastoral Theology was created at the University. It was to educate seminarians as loyal Austrian clerks. In Statut organiczny (Organic Statute) from 1818 the University was called 'Jagiellonian.' In 1846, the Republic of Kraków created at the Congress of Vienna, was annexed to the Austrian Empire. The Faculty of Theology was again within the borders of the Austrian Empire and suffered the most devastating blow. In 1847, in virtue of a monarch's decree the Faculty was deprived of the right of doctor's conferral.

During this extremely difficult period there originated the institution of a private docent as a completely new organisational and didactic element at the Faculty. The institution of a private docent, for the first time introduced at the University of Berlin in 1816, was accepted in Austria only in 1848 and at the Jagiellonian University only in 1862. (Fryderyk Zoll at the Faculty of Law and Administration). At the Faculty of Theology the first habilitation degree was awarded in 1867, when Fr. Jan Droździewicz (1812-1888) attained veniam legendi in patrology and later became a professor of patrology and from 1872 was a lecturer on the Old Testament and the Oriental languages. Soon the habilitation examination would assure theof holding of a university chair.

During that period the Faculty had professors of outstanding achievements. The pioneering work Compedium hermeneuticae generalia librorum Veteris et Novi Foederis usui studiosorum Sacrae Scripturae accommodatum ${ }^{26}$

${ }^{26}$ Vol. 1-2 Cracoviae 1817-1821. 
by Father Florian Kudrewicz, a Basilian, (1766-1834), one of the most distinguished Polish biblical scholars in the first half of the $19^{\text {th }}$ century, was commonly used in all Polish theological departments. Fr. Ignacy Penka (1793-1855) wrote a highly esteemed, original manual Praelectiones ex theologia dogmatica ${ }^{27}$, in which a thoroughly erudite explanation of faith in a wide context of moral theology, history of dogmas, patristics and Church history dominated over a polemic with contrary views. Fr. Leon Laurysiewicz (1798-1854), a professor of pastoral theology, lectured on the ministry of the deaf-mute, which was a complete novelty at the University.

\section{Second spring}

The re-organisation of the Faculty in 1880 was very crucial. It restored full academic rights and the increasing number of chairs initiated a period of intense re-building of the University's role in Polish culture, which it had enjoyed in the $15-16^{\text {th }}$ centuries. In $1880-1939$, the Faculty experienced something similar to a second spring, comparable with its golden $15^{\text {th }}$ century.

After the announcement of the encyclical Aeterni Patris by Pope Leo XIII in 1879 the regenerating scholastics experienced a strong impulse to its development. The lectures on neo-Thomistic philosophy were introduced at the Faculty of Theology of the Jagiellonian University in 1880. They were delivered by Fr. Zygmunt Golian (1824-1885), one of the most eminent early Polish neo-scholastics. In 1882, the first Chair of Christian Philosophy in the Austro Hungarian Empire was created at the Faculty of Theology. It was given to Fr. Stefan Pawlicki, C.R. (1839-1916), an erudite philosopher and apologist of European rank. He was a professor of fundamental theology from 1883. In his works $O$ początkach chrześcijaństwa (About the Beginnings of Christianity) ${ }^{28}$ and Żywot i dzieła Ernesta Renana (The Life and Works of Ernest Renan) ${ }^{29}$ he carried out a penetrating critique of rationalistic attempts to solve the problem of the origin of Christianity and he discussed the key apologetic issues of authenticity and reliability of the Gospel, the teaching on miracles as verifying the divinity of Christ's mission and the primacy of St. Peter. In his university

\footnotetext{
${ }^{27}$ Vol. 1-4 Cracoviae 1844-1845.

${ }^{28}$ Kraków 1884.

${ }^{29}$ Kraków 1896; $3^{\text {rd }}$ edition in Warsaw 1905.
} 
manuals Logika formalna (Formal Logic) ${ }^{30}$, Noetyka (Noesis) ${ }^{31}$, Metafizyka ogólna czyli nauka o bycie (General Metaphysics that is the Teaching on Being) ${ }^{32}$, Psychologia (Psychology) ${ }^{33}$, Filozofia przyrody (Philosophy of Nature) ${ }^{34}$ and Logika ogólna (General Logic) ${ }^{35}$ Fr. Franciszek Gabryl (1866-1914) presented almost the whole system of neo-scholastic philosophy.

One of the most prominent European neo-scholastics was Fr. Marian Ignacy Morawski, S.J. (1845-1901), an equally outstanding philosopher and theologian, who was a professor of dogmatic theology in 1887-1899. His most important philosophical works remained Filozofia i jej zadania (Philosophy and its Tasks) ${ }^{36}$, Celowość wnaturze (Purposefulness in Nature) ${ }^{37}$ and Podstawy etyki i prawa (The Principles of Ethics and Law $)^{38}$. He combined philosophical issues with his interests in apologetics in which he achieved European status. His extraordinary position in the history of the Polish apologetic thought was based on the classic scheme of three elements: religion, Christian revelation and Catholic Church. The justification of his views were masterfully carried out in Wieczory nad Lemanem (Evenings over the Lake of Leman) ${ }^{39}$. This short work had 12 editions in Polish and 16in foreign languages. Fr. Ignacy Morawski, Polish Chateaubriand, was regarded as a creator of a new kind of theological writing in Poland called 'world outlook literature.'

Fr. Józef Krukowski (1828-1900) wrote a manual Teologia pasterska katolicka dla użytku duchownych seminariów i pasterzów dusz (Catholic Pastoral Theology for the Use of Theological Seminaries and Shepherds of Souls $)^{40}$, in which he presented the exposition of general pastoral theology, homiletics, catechesis and liturgics with a wide treatment of the sacrament of penance. At the end of the $19^{\text {th }}$ century this compendium was the most

\footnotetext{
${ }^{30}$ Kraków 1899.

31 Kraków 1900.

32 Kraków 1903.

33 Kraków 1906.

34 Kraków 1910.

35 Kraków 1912.

36 Lvov 1877, $3^{\text {rd }}$ edition, Kraków 1899.

37 Kraków 1887, $6^{\text {th }}$ edition, Kraków 1928.

38 Kraków 1891, 4 ${ }^{\text {th }}$ edition, 1930.

39 „Przegląd Powszechny” 1893-1896.

${ }^{40}$ Lvov 1874; $4^{\text {th }}$ edition, Kraków 1894.
} 


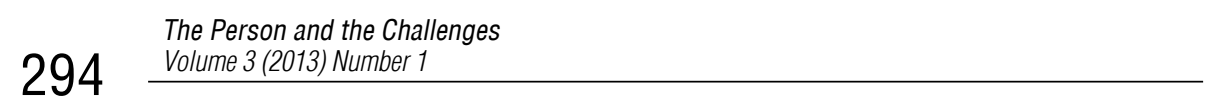

widespread pastoral manual in Polish theological seminaries in all of the three partitions. His manuals on religious instruction were edited several times.

In the field of the theology of spiritual life St. Józef Sebastian Pelczar (18421924 ) is worth mentioning. Later he became the Latin rite bishop of Przemyśl. For over 50 years his work Życie duchowne czyli doskonałość chrześcijańska (Spiritual Life, that is Christian Perfection) ${ }^{41}$, an original synthesis based on the classic ascetic literature, was an obligatory introduction to spiritual life issues at seminaries and religious noviciates. On the basis of his lectures on canon law he wrote a large work Prawo matzeńskie katolickie z uwzględnieniem prawa cywilnego obowiazującego w Austrii, w Prusach $i$ w Królestwie Polskim (The Law of Catholic Matrimony Including the Civil Law Obligatory in Austria, Prussia and the Polish Kingdom $)^{42}$. It was the first manual in Polish and in those days, the only large manual, at the same time being a practical handbook on marital law. He also wrote the first Polish manual Medycyna pasterska czyli wiadomości potrzebne kapłanowi z zakresu hygieny, fizyologii i patologii $z$ dodatkiem niektórych kwestii teologicznych (Pastoral Medicine, that is information on hygiene, physiology and pathology including some theological questions that a priest needs $)^{43}$. His small work Masonerya, jej początki, organizacja, ceremoniat, zasady i dziatanie (Freemasonry, its Beginnings, Organisation, Rites, Principles and Activities) ${ }^{44}$ aroused a wide social interest. It was the first Polish description of freemasonry in the world. Fr. Tadeusz Gromnicki (1851-1939) wrote valuable works on the history of ecclesiastical law: Synody prowincjalne oraz czynności niektórych funkcjonariuszów apostolskich w Polsce do roku 1357 (Provincial Synods and the Activities of some Apostolic Officials in Poland till 1357) $)^{45}$ and Świętopietrze $w$ Polsce (Peter's Pence in Poland) ${ }^{46}$. Fr. Władysław Chotkowski (1843-1926) wrote a work fundamental to be acquainted with the history of the Church under Austrian rule: Historia polityczna dawnych klasztorów panieńskich w Galicji 1773-1848 na podstawie akt Cesarskiej Kancelarii Nadwornej (Political History of Women's Old Cloisters in Galicia in 1773-1848 on the Basis of

\footnotetext{
${ }^{41}$ Przemyśl 1873; $8^{\text {th }}$ edition, Kielce 1924.

${ }^{42}$ Kraków 1882; $4^{\text {th }}$ edition in 1898.

${ }^{43}$ Lvov 1900; $3^{\text {rd }}$ edition in 1908.

${ }^{44}$ Przemyśl 1905; $4^{\text {th }}$ edition, Kraków 1914.

${ }^{45}$ Kraków 1885.

${ }^{46}$ Kraków 1908.
} 
the Acts of the Emperor's Chancellery) ${ }^{47}$ and Historia polityczna Kościoła w Galicji za rzadów Marii Teresy 1772-1780 (Political History of the Church in Galicia under the Rule of Maria Theresa, 1772-1780) ${ }^{48}$.

Lectures were conducted in Latin. Only pastoral theology and catechesis, homiletics and liturgics were taught in Polish. A scientific seminar played an indispensable role in university teaching. The formative relation between master and disciple is evidently manifested in such a seminar. At the Faculty of Theology of the Jagiellonian University the dean of the Faculty at that time, Fr. Władysław Chotkowski, introduced disputatoria historica in the academic year 1882/83. Fr. Stefan Pawlicki began his dialectic classes in 1884/85. In 1888, the Ministry of Religions and Education sanctioned the provisional statutes of seminars: Church history and philosophical-scholastic. They were the first seminars in the theological faculties in Austro-Hungary. At the Faculty of Theology of the Vienna University seminars were introduced only in 1899/1900. Other chairs of the Kraków Faculty opened seminars only in 1906/07.

A considerable increase in Catholic thought and social work after the encyclical Rerum novarum by Pope Leo XIII in 1891 inspired universities to introduce a regular course of Catholic teaching on social matters, then called Christian sociology or Christian social teachings. In 1910, a Chair of Christian Social Teaching was created at the Faculty of Theology of the Jagiellonian University (the first one in Austro-Hungary). It was directed by Fr. Kazimierz Zimmermann (1874-1925), a doctor of political economics at the University of Münich, a well-known social activist in the region of Great Poland. Fr. Franciszek Gołba (1862-1944) translated, philologically interpreted, and edited Trzy aramejskie papirusowe dokumenty z Elefantyny (Three Aramaic Papyri from Elephantine) ${ }^{49}$ and wrote Metrum $w$ poezji hebrajskiej (Meter in Hebrew Poetry) ${ }^{50}$.

After Poland had regained independence in 1918, there was a great need for lecturers in the newly organised universities. The Jagiellonian University helped them with staffing. The Faculty of Theology joined in this effort. In the years 1918-1939, there was no single faculty of theology in Poland without

\footnotetext{
47 Kraków 1905.

${ }^{48}$ Kraków 1909.

49 Kraków 1908.

50 Kraków 1913.
} 
scholars connected cum Alma Matre Jagellonica either by habilitation or doctor's conferment.

After the period of national slavery the Church in Poland inherited two faculties of theology, which had already been created before the partitions: in Kraków (1397) and in Lvov (1661), their structures being similar to the Austrian and German faculties. In the restored country faculties of theology were created at the new universities in Warsaw and Lublin as well as at the re-opened university in Vilnius, which had been closed in 1832 by the Russian authorities after the failure of the January Uprising (1831). There was no faculty of theology in Poznań. The organisation of faculties in Warsaw and Lublin was based on the model of the Roman higher schools. The Faculty of Theology at the new University of Vilnius was adjusted to the structure of the Kraków and Lvov Faculties. Therefore, in the interwar period Poland had five faculties of Catholic theology. The Faculties in Warsaw and Lublin were open only to alumni of seminaries. The aim was to widen and deepen their completed philosophical and theological studies and then go on to specialise. The admission requirement in the Faculties of Theology in Kraków, Lvov and Vilnius was the certificate of completion of grammar school. At the same time students of these faculties were alumni of the diocesan or sometimes religious seminaries. After graduation they were ordained. The more talented ones could achieve academic degrees. In the academic year 1919/20, five-year studies were introduced. The former practice was four years. Latin as the language of instruction was used only in the chairs of fundamental theology and specific dogmatic theology, moral theology and canon law. The remaining disciplines were taught in Polish. In the 1920s the use of Latin was further limited. Only canon law was lectured in Latin. Latin was partly used in philosophy and dogmatic and moral theologies.

The Kraków metropolis was one of the five Latin Church provinces, which resulted from the division of Poland in virtue of the concordat with the Holy See concluded in 1925. A formal erection of the Kraków metropolis was made by Pope Pius XI with the bull Vixdum Poloniae unitas. Beside the Kraków Archbishopric the following dioceses were included in the metropolis: Tarnów and Kielce and two new ones of Częstochowa and Katowice. The newly created dioceses did not have their own seminaries or proper staff. However, the Jagiellonian University with its Faculty of Theology was within the Kraków metropolis and from the academic year 1921/22 the Faculty of Theology was the biggest theological faculty in Poland. A special scientific and cultural climate of this oldest Polish university and outstanding personalities in the 
staff of the Faculty of Theology created particularly profitable conditions for a thorough and versatile education of clergy. For this reason in 1926 Bishop Teodor Kubina of Częstochowa and Bishop August Hlond of Katowice, then the Primate of Poland, decided to educate their seminarians in Kraków, where they built seminaries for their dioceses. After their establishment in Kraków the number of students of theology increased considerably and ranged from 217 in 1926/27 to 397 in 1933/34. The Kraków Faculty had the biggest number of students in Poland. There were also American, German, Romanian and Czech students of Polish background. One could meet Germans, Slovaks, Ukrainians and even Frenchmen at the Faculty.

In 1931, Pope Pius XI announced his apostolic constitution Deus scientiarum Dominus on universities and faculties of ecclesiastical studies in order to raise the level of studies and to introduce a uniform system of theological education in the whole Church. The supplementary executive instructions of the Sacred Congregation for Seminaries and Universities ordered six year philosophical-theological studies. The first two years were to include the study of Christian philosophy and the next four - theology. At the Faculty of Theology in Kraków this demand was met by combining the second year of philosophy with the first year of theology. The studies still lasted five years.

From the beginning of the $20^{\text {th }}$ century the pride of the Jagiellonian University was Fr. Jan Fijałek (1864-1936), still regarded as the most distinguished historian in the Polish Church. Despite the lapse of many years his works did not lose their value, not only because of the richness of content but also because of his method of research. His most important works include: Studia do dziejów Uniwersytetu Krakowskiego i jego Wydziału Teologicznego w XV wieku (Studies of the History of the Kraków University and its Faculty of Theology in the $15^{\text {th }}$ century) $)^{51}$ and in particular Mistrz Jakub z Paradyza $i$ Uniwersytet Krakowski w okresie soboru bazylejskiego (Master Jacob of' Paradyz and the Kraków University during the Council of Basle $)^{52}$. He contributed greatly in the field of publishing historical sources. He edited Najstarsze statuty synodalne krakowskie biskupa Nankera z 2 października 1320 r. (The Oldest Synodal Kraków Statutes of Bishop Nanker of 2 October

\footnotetext{
51 Kraków 1899.

52 Vol. 1-2, Kraków 1900.
} 
1320) ${ }^{53}$, Statuty kapituly katedralnej wtoctawskiej (The Statutes of the Chapter of the Wtoctawek Cathedral) prepared by Fr. Stanisław Chodyński ${ }^{54}$, Kodeks dyplomatyczny katedry i diecezji wilenskiej (The Diplomatic Codex of the Vilnius Cathedral and Diocese) $)^{55}$ and Zbiór dokumentów zakonu OO. Paulinów $w$ Polsce (The Collection of the Documents of the Pauline Order in Poland) ${ }^{56}$. His publications were characterised by an extraordinary precision and could compete with the best foreign editions of that kind. In 1918-1921, he was the editor of the scientific magazine 'Polonia Sacra,' and after its bankruptcy due to financial difficulties, he edited 'Nova Polonia Sacra' (1926-1928).

During the interwar period, the Faculty of Theology of the Jagiellonian University still produced imposing achievements in Christian philosophy. The Kraków school of philosophy was mostly historical. Fr. Konstanty Michalski, C.M., (1879-1947), pride of Polish science of the interwar period, was the Polish scholar who working on the explanation of main trends in philosophy in late medieval England and in France of the $14^{\text {th }}$ century, made a powerful and significant contribution to European science. The medieval treatises of Fr. K. Michalski: Les courants philosophiques à Oxford et à Paris pendant le XIV siècle; Le criticisme et la scepticisme dans la philosophie du XIVe siècle; Les courants critiques et sceptiques dans la philosophie du XIV siècle; La physique nouvelle et les differents courants philosophiques au XIVe siècle ${ }^{57}$, Wplyw Oksfordu na filozofie Jana z Mirecourt (The Influence of Oxford on the Philosophy of John of Mirecourt) ${ }^{58}$, Odrodzenie nominalizmu $w$ XIV wieku (The Revival of Nominalism in the $14^{\text {th }}$ century) ${ }^{59}$ and Le problème de la volonté à Oxford et à Paris au XIVe siècle $)^{60}$ made him one of the international authorities in the field of medieval philosophy, one of the few historians who changed the views of the history of European thought.

${ }^{53}$ Kraków 1915.

54 Kraków 1916.

55 Vol. 1, issue 1, Kraków 1932, issue 2, Kraków 1939, co-edited with W. Semkowicz.

${ }^{56}$ Issue 1, 1328-1464, Kraków 1938.

57 "Bulletin International et des Lettres. Clase d'histoire et de philosophie" 1919, 1920; 1925, issues $1-10 ; 1927$, issues $4-6$.

58 Series II of Dissertations de l'Academie Polonaise des Sciences, The Historical-Philosophical Faculty, vol. 38.

59 “Kwartalnik Filozoficzny" (Philosophical Quarterly) 4:1926.

60 Studia Philosophica II, Leopolli 1937. 
The scientific interests of Fr. Jan Salamucha (1903-1944) focused mainly on the history of ancient and medieval philosophy, taking logic into special consideration. In his historical researches he used strict methods of mathematical logic. He exposed the discrepancies in Aristotle's theory of deduction (Pojęcie dedukcji u Arystotelesa $i s ́$ w. Tomasza z Akwinu - The Idea of Deduction in Aristotle and St. Thomas Aquinas) ${ }^{61}$. He proved that William of Ockham was the most outstanding medieval expert of the logic of sentences (Logika zdan $u$ Wilhelma Ockhama-Logic of Sentences by William of Ockham ${ }^{62}$. He proved the authenticity of the treatise on the so-called insolubles (that cannot be solved) in Suma logiczna (Logical Summa) by Ockham (Pojawienie się zagadnień antymonialnych na gruncie logiki średniowiecznej - The Appearance of Antymonial Issues in the Field of Medieval Logic ${ }^{63}$. He formalised the evidence of God's existence from Summa contra gentiles and showed that St. Thomas' reasoning went beyond the framework of Aristotle's logic (Dowód ex motu na istnienie Boga. Analiza logiczna argumentacji Tomasza z Akwinu - Proof ex motu of God's existence. Logical Analysis of the Argumentation of St. Thomas Aquinas $)^{64}$. It was the first mathematical-logical analysis of the existence of God.

Fr. Maciej Sieniatycki (1869-1949) made his name known in Polish theology with his university manuals: Zarys dogmatyki katolickiej (An Outline of Catholic Dogmatics ${ }^{65}$ and Apologetyka czyli dogmatyka fundamentalna (Apologetics, that is Fundamental Dogmatics) ${ }^{66}$, in which he defined Polish terminology in dogmatic theology. His manuals were soon accepted in almost all of the theological departments in Poland.

Fr. Józef Archutowski (1879-1944) achieved a high position in biblical studies due to his hand-books: Wstęp szczegółowy do ksiag świętych Starego Testamentu (Detailed Introduction to the Old Testament Books) ${ }^{67}$ and O natchnieniu Pisma Świętego (About the Inspiration of the Bible) ${ }^{68}$, which equalled the level of other international university books. However, his most distinguished biblical

\footnotetext{
61 Warszawa 1930.

62 "Przegląd Filozoficzny" (Philosophical Review) 38:1935.

63 "Przegląd Filozoficzny" (Philosophical Review) 40:1937.

64 "Collectanca Theologica" 15:1934.

${ }^{65}$ Vol. 1-4, Kraków 1928-1931; $2^{\text {nd }}$ edition in 1933-1936.

${ }^{66}$ Kraków 1932.

${ }^{67}$ Kraków 1927.

${ }^{68}$ Kraków 1930.
} 
manual, highly evaluated in scientific circles, was Historia i krytyka tekstu hebrajskiego Starego Testamentu (The History and Text Criticism of the Hebrew Old Testament ${ }^{69}$. He was the initiator and participant of almost all national biblical events. In 1937-38 he edited and published 'Biblical Review,' following the pattern of French 'Revue Biblique.'

The source-books and in many cases pioneering works of Fr. Władysław Wicher (1888-1969): Ks. Szymon Stanistaw Makowski-moralista polski z XVII wieku (Fr. Szymon Stanistaw Makowski - Polish Moralist in the $17^{\text {th }}$ century) ${ }^{70}$ and O. Marcina Śmigleckiego SJ „Traktat o lichwie i procentach” $w$ świetle współczesnej i późniejszej nauki teologów (Fr. Marcin Śmiglecki's, S.J. 'Treatise on Usury and Percentage' in the Light of Contemporary and Later Teaching of Theologians $)^{71}$ continue to be used by historians of theology. One of the most eminent Polish specialists on canon law of that period was Fr. Jan Krzemieniecki (1887-1956) who explained the canonical administrative procedure (Procedura administracyjna w Kodeksie Prawa Kanonicznego - Administrative Procedure in the Code of Canon Law ${ }^{72}$, Gtówne warunki ważności kanonicznego procesu administracyjnego - The Main Conditions of Validity of Canonical Administrative Trial) ${ }^{73}$ and researched the sources of Polish ecclesiastical law. Fr. Tadeusz Kruszyński (1884-1959), a historian of Church art, meritorious for restoring the stannic royal sarcophagi in the crypt of the Wawel cathedral, was a distinguished expert on Polish and international historical weaving. Bishop Michał Godlewski (1872-1956), a professor of Church history, was famous for his preaching. His lectures, delivered in excellent Polish with subtle humour, slight irony and frequent anecdotes, had an enormous audience. He was an expert and editor of the sources of the Catholic Church in Russia among which two large collections are worth mentioning: Monumenta Ecclesiastica Petropolitana ${ }^{74}$ and Journal et correspondance de Stanislas Siestrzeńcewicz-Bohusz premier archevêque métropolitain de toutes les Église catholique en Russie $)^{75}$. The most important works of Fr. Tadeusz Glemma (1895-1958), successor of Fr. Jan

\footnotetext{
${ }^{69}$ Kraków 1938.

70 Kielce 1926.

${ }^{71}$ Lvov 1936.

72 Kraków 1925.

${ }^{73}$ Kraków 1930.

74 Vol. 1-5, Petersburg 1906-1913.

75 Vol. 1-5, Petersburg 1913-1917, together with N. Kriksin.
} 
Fijałek at the Chair of Church History in Poland, remained: Stosunki kościelne w Toruniu w stuleciu XVI i XVII na tle dziejów kościelnych Prus Królewskich (The Ecclesiastical Relations in Torun in the $16^{\text {th }}$ and the $17^{\text {th }}$ centuries in the Background of Ecclesiastical History of Royal East Prussia) ${ }^{76}$ and Wydziat Teologiczny Uniwersytetu Jagiellońskiego w latach 1795-1847 (The Faculty of Theology of the Jagiellonian University in 1795-1847) 77 . The fact that many professors (W. Chotkowski, J. Fijałek, T. Glemma, M. Godlewski, K. Michalski, S. Pawlicki) became members of the Academy of Arts and Sciences, and from 1919 the Polish Academy of Arts and Sciences embracing the elite of the nation, was an expression of high esteem for their scientific achievements.

During the interwar period Kraków was a well-known centre of the Polish movement of liturgical revival, its precursor being Fr. Jan Korzonkiewicz (18771932), a former professor of the Old Testament. The pioneer of the movement was Fr. Michał Kordel, a disciple of Fr. Korzonkiewicz. Fr. Kordel was the founder of 'Misterium Christi,' the first Polish magazine devoted to the service of God, published in Kraków in 1929-1935 and being similar to an organ of the liturgical movement in Poland. Published in thousands of copies, the works of Fr. Kordel: Mszat niedzielny i świateczny (Sunday and Feast Missal) ${ }^{78}$ and Mszat Rzymski w polskim przektadzie. Wydanie zupetne na wszystkie niedziele, święta i dni całego roku kościelnego (Roman Missal in Polish Translation. Full Edition for All Sundays, Feasts and Days of the Liturgical Year $)^{79}$ in comparison with popular German missals, made him into the Polish [Anzelm] Schott.

\section{Years of struggles with violence}

The successful development of the Faculty was dramatically broken by the outbreak of World War II in September of 1939 and the following gehenna of the Nazi occupation. On 6 November 1939, 144 professors and lecturers of the Jagiellonian University were arrested treacherously in the ill-famed Sonderaktion Krakau. Among the arrested were 10 professors and lecturers of the Faculty of Theology, which constituted $83 \%$ of the faculty staff. The

\footnotetext{
76 Toruń 1934.

77 Kraków 1949.

78 Kraków 1935.

${ }^{79}$ Kraków 1936, $2^{\text {nd }}$ edition in 1939.
} 
following priests were arrested: Józef Archutowski, a biblical scholar (Old Testament); Antoni Bystrzonowski, a pastoral theologian; Tadeusz Glemma, a historian; Józef Kaczmarczyk, a biblical scholar (New Testament); Tadeusz Kruszyński, a historian of art; Jan Krzemieniecki, a lawyer; Konstanty Michalski, a philosopher; Marian Michalski, a patrologist; Jan Salamucha, a philosopher and logician and Władysław Wicher, a moral theologian. Many professors of the Jagiellonian University did not live to see the day of the professors' liberation - 8 February 1940 (their liberation was possible due to the numerous tempts of the diplomatic, international academic circles and particular scientific authorities, and the Holy See). On that day all of the professors of the Faculty of Theology were released, except M. Michalski and J. Salamucha who were taken to the camp in Dachau near Münich and suffered for one more year. Those professors were not freed until 4 January 1941. During the war (1939-45) four professors and lecturers of the Faculty gave their lives for their country.

The SS shock troops guarding the Kraków castle seized control of the archdiocesan seminary building on 8 November 1939. Archbishop Adam Stefan Sapieha moved the fourth and fifth years of theological studies to his palace at 3 Franciszkańska Street. The younger seminarians were moved to the Catholic House (now the Philharmonic Hall). Having been removed from this building on 9 December 1941, they were accommodated in the Bishops' Palace. The Częstochowa Seminary was thrown out of its own building at 3 Bernardyńska Streeton 2 November 1939, to which the Gestapo relocated. The seminarians moved to the neighbouring Bernardine monastery and partly to the archbishop's seminary. Then they were accommodated in the buildings of various Kraków monasteries. A Nazi police station (schupo) occupied the building of the Silesian seminary. The Jagiellonian University was closed. The secret theological studies were directed by Fr. Tadeusz Glemma, who remained in close contacts with Archbishop Sapieha.

After the liberation of Kraków from the Nazi occupation on 18-19 January 1945, the University quickly began its normal academic-didactic activities. The Faculty of Theology, having the permission of the Ministry of Education, acknowledged the secret theological courses as university studies needed for the graduation and pursuit of a master's degree. The extremely hard times, marked with suffering and sacrifice of life, were the years of university iter scholasticum of Fr. Karol Wojtyła, later Pope John Paul II, the unquestionable moral authority for all people of good will, an outstanding scholar, theologian and philosopher. He began his studies at the Faculty of Philosophy (Polish 
Philology) in October 1938, and then from 1942 he continued his studies of theology in the clandestine courses at the Faculty of Theology.

After the war the Faculty of Theology of the Jagiellonian University, as in 1939, held 12 chairs: two of Christian Philosophy; Studies of the Old Testament; Studies of the New Testament; Fundamental Theology; Detailed Dogmatic Theology; History of Dogmas and Patrology; Moral Theology; Pastoral Theology; Canon Law and two chairs of Church History. In this period the Faculty of Theology had many distinguished scholars. The greatest pride of the Jagiellonian University remained Fr. Karol Wojtyła, later Pope John Paul II, a lecturer on social ethics, the last who had his habilitation before the liquidation of the Faculty of Theology. Fr. Kazimierz Kłósak (1911-1982) won wide fame due to his polemic with dialectical materialism and critical evaluation of the views of Teilhard de Chardin. However, he primarily focused on specific issues: of proofs for God's existence, the origin and structure of human soul, issues of cognitive possibilities and limits of natural sciences. Fr. Ignacy Różycki (19111983), who considered theology as a scientific exposition of the Church beliefs, focused on the problems of methodology in dogmatic theology. Fr. Aleksy Klawek (1890-1969) was an outstanding biblical scholar and Orientalist who analysed mainly the issues in the Book of Genesis and the Book of Psalms. In 1948, he founded a bimonthly 'Ruch Biblijny i Liturgiczny' (Biblical and Liturgical Movement). After 1945 the students of the Faculty of Theology were not only the alumni of the above-mentioned diocesan seminaries but also for a short time the alumni of the Wrocław archdiocese and apostolic administration of Śląsk Opolski. There were also students of various religious communities. After the opening of regular studies in 1945, the Faculty had 114 students. In the next academic year (1945/46) there were 207. The number increased every year, reaching 476 students in 1950/51. During the last three years of the activities of the Faculty within the structure of the Jagiellonian University, the number of students was decreasing. In the academic year 1953/54 there were only 343 students at the Faculty. The decrease in the number of students was undoubtedly due to the restrictive policy of the government towards the Faculty.

The struggle with the Church, atheistic policy and laicisation planned by the communist government prevented a normal development of the Faculty outright. The attempts to create chairs of Christian Pedagogy and Catechesis and History of Literature on Preaching did not succeed. The Ministry of Education, and then the Ministry of Higher Education, limited the funds for didactic activities, stubbornly refused to acknowledge habilitations and nominations 
of new professors. A six-year programme of studies was not permitted. The basic course of philosophical-theological studies lasted five years until 1961. The faculty's existence was in jeopardy. The threat of liquidation appeared unavoidable and then it was a fact. The Faculty of Theology - the work of Saint Queen Jadwiga - after more than 500 years of service in the oldest Polish university, was removed from the University. The Council of Ministers of the Polish People's Republic by its unilateral decision of 11 August 1954, without any agreement with the Church, connected the Faculty of Theology of the Jagiellonian University to the Faculty of Catholic Theology of the Warsaw University to form the Academy of Catholic Theology in Warsaw, which was created purely by the socialist government. For two more years the seminarians, former students of the Faculty of Theology, studied in the Church buildings. Then the Archdiocese of Kraków and the dioceses of Częstochowa and of Katowice organised theological studies in their seminaries.

\section{The school of John Paul II}

The Faculty of Theology in Kraków survived as an autonomous faculty due to the uncompromising attitude of the Apostolic See and Kraków bishops. The Sacred Congregation for Seminaries and Universities in the Vatican, with its decree of 16 December 1959, stated that the Kraków Faculty of Theology still 'remained under the supervision of one ecclesiastical authority and in the future is to be formed according to the laws passed by the Apostolic See' ${ }^{80}$. In 1974 the Faculty, functioning within the Metropolitan Seminary, was bestowed the title 'pontifical.'

A turning point in the history of the Faculty was its re-structuring into an academy with three faculties. On 8 December 1981 Pope John Paul II established the Pontifical Academy of Theology in his motu proprio Beata Hedvigis: 'granting it the rights, honours, privileges and responsibilities justly entitled to all similar schools in the whole Catholic world. [...] The Academy at present consisting of three ecclesiastical faculties: Sacred Theology, Philosophy and Church History, should be governed by the academic laws of

${ }^{80}$ The Archives of the Pontifical University in Kraków, PWT 0110, Decree of the Sacred Congregation for Universities, Rome 16 December 1959. 
the Church'81. The motu proprio Beata Hedvigis was issued a few days before the imposition of martial law in Poland (13 December 1981). The contacts between the Apostolic See and the Church in Poland were restricted as well as the broadcast of information inside the country. Therefore, the news about the erection of the Pontifical Academy of Theology reached Kraków only at the turn of 1981/82. The inauguration of the first academic year of the Pontifical Academy of Theology in Kraków was held in St. Anne's Church on Sunday, 17 October 1982. The press gave publicity to that event defining the Academy as the continuation of the Faculty of Theology of the Jagiellonian University and at the same time a new institution of higher education in Poland. The academic environment in Kraków welcomed the new theological school with approbation. However, the state authorities assumed a decisively negative attitude towards the new theological school within a very short time. The problem of acknowledgement of the Pontifical Academy of Theology in Kraków by the state became a subject of negotiations between the representatives of the Polish Church and the Apostolic See on the one hand and the representatives of the state authorities on the other. It was not until 1989 that the authorities of the Polish People's Republic finally acknowledged the Academy.

There were two distinguished philosophers among the professors of the Academy, namely Father Tadeusz Wojciechowski (1917-2000), a propagator of the theistic theory of evolution and Father Józef Tischner (1931-2000), who was involved in a brave and at the same time creative dialogue with the contemporary socialist thought. Two biblical scholars, Fr. Władysław Smereka (1907-1983) and Fr. Stanisław Grzybek (1915-1998), translators of some books of the Holy Scriptures (the so-called Biblia Tysiaclecia and Biblia Poznańska), also became well-known professors. The Academy continued to develop. New organisational structures were created. In the year 2004a branch campus of the Faculty of Theology was opened in Tarnów. In 2008, the Faculty of Social Sciences was called into being.

On 19 June 2009 Pope Benedict XVI, fulfilling the request of Cardinal Stanisław Dziwisz, the Archbishop of Kraków and Great Chancellor of the Pontifical Academy of Theology, elevated the Academy to 'the Pontifical University in Kraków named after John Paul II to develop ecclesiastical sciences' in order to 'commemorate the memory of his outstanding Predecessor,

${ }^{81}$ Litterae apostolicae motu proprio Beata Hedvigis datae Pontificia Acadeinia Theologica Cracoviensis constituitur, "Acta Apostolicae Sedis" 74 (1982), p. 372. 
the Servant of God John Paul II ${ }^{82}$. The University realises its educational and academic activities within five faculties: the Faculty of Philosophy, the Faculty of History and Cultural Heritage, the Faculty of Social Sciences, the Faculty of Theology and the branch campus of the Faculty of Theology - Theological Section in Tarnów.

The Pontifical University continues, in accordance with the contemporary needs of the Church in Poland, its historical mission of the Faculty of Theology of the Jagiellonian University. The Pontifical University pays much attention to developing philosophical investigations, heading for a creative connection between the great tradition of Christian thought and achievements of the contemporary world. Because of the unique role of Kraków in the history of national Christian culture the Pontifical University pays much attention to the history of religious life in Poland.

The Pontifical University of John Paul II in Cracow has become part of the six hundred plus year heritage of the Faculty of St Queen Jadwiga and through its professors, lecturers, graduates and students, it brings the heritage into the contemporary service of the evangelization of nations.

\section{Bibliography}

Barcik M., Wydziat Teologiczny Uniwersytetu Jagiellońskiego (1939-1954), Kraków 2001, (Studia do dziejów Wydziału Teologicznego Uniwersytetu Jagiellońskiego 13/1).

Kanior M., Wydziat Teologiczny $w$ dziejach Uniwersytetu Krakowskiego (17801880), Kraków 1998, (Studia do dziejów Wydziału Teologicznego Uniwersytetu Jagiellońskiego 8).

Markowski M., Dzieje Wydziatu Teologii Uniwersytetu Krakowskiego w latach 13971525, Kraków 1996, (Studia do dziejów Wydziału Teologicznego Uniwersytetu Jagiellońskiego 2).

Piech S., Dzieje Wydziału Teologicznego Uniwersytetu Jagiellońskiego w latach 1880 1939, Kraków 1995, (Studia do dziejów Wydziału Teologicznego Uniwersytetu Jagiellońskiego 6).

Piech S., Six Centuries of the Faculty of Theology in Cracow, "Analecta Cracoviensia" 29 (1997), pp. XXXV-LIV.

Piech S. (ed.), Wydział Teologiczny w Krakowie 1397-1997, Kraków 1997.

Piech S. (ed.), Złota Księga Papieskiej Akademii Teologicznej (Liber Aureus Pontificiae Academiae Theologicae), Kraków 2000.

\footnotetext{
${ }^{82}$ Decree of the Congregation for Catholic Education, issued on 19 June 2009.
} 